\title{
Integrated monitoring of mountain glaciers as key indicators of global climate change: the European Alps
}

\author{
Wilfried HAEBERLI, Martin HOELZLE, Frank PAUL, Michael ZEMP \\ Glaciology and Geomorphodynamics Group, Department of Geography, University of Zürich, Winterthurerstrasse 190, \\ CH-8057 Zürich, Switzerland \\ E-mail: haeberli@geo.unizh.ch
}

\begin{abstract}
The internationally recommended multi-level strategy for monitoring mountain glaciers is illustrated using the example of the European Alps, where especially dense information has been available through historical times. This strategy combines in situ measurements (mass balance, length change) with remote sensing (inventories) and numerical modelling. It helps to bridge the gap between detailed local process-oriented studies and global coverage. Since the 1980s, mass balances have become increasingly negative, with values close to $-1 \mathrm{~m}$ w.e. $\mathrm{a}^{-1}$ during the first 5 years of the $21 \mathrm{st}$ century. The hot, dry summer of 2003 alone caused a record mean loss of $2.45 \mathrm{~m}$ w.e., roughly $50 \%$ above the previous record loss in 1998, more than three times the average between 1980 and 2000 and an order of magnitude more than characteristic long-term averages since the end of the Little Ice Age and other extended periods of glacier shrinkage during the past 2000 years. It can be estimated that glaciers in the European Alps lost about half their total volume (roughly $0.5 \% \mathrm{a}^{-1}$ ) between 1850 and around 1975, another $25 \%\left(\right.$ or $1 \% \mathrm{a}^{-1}$ ) of the remaining amount between 1975 and 2000, and an additional $10-15 \%\left(\right.$ or $\left.2-3 \% \mathrm{a}^{-1}\right)$ in the first 5 years of this century.
\end{abstract}

\section{INTRODUCTION}

Mountain glaciers are key indicators and unique demonstration objects of global climate change (Houghton and others, 2001). As a consequence, they are an 'essential climate variable' in the terrestrial part of the Global Climate Observing System (GCOS/GTOS). The corresponding monitoring network, the Global Terrestrial Network for Glaciers (GTN-G), is run by the World Glacier Monitoring Service (WGMS) in close cooperation with the Global Land Ice Measurements from Space (GLIMS) initiative (Bishop and others, 2004; Bamber, 2006; Kääb, 2006; cf. GCOS, 2003, 2004; Haeberli, 2004). The monitoring network uses an integrated, multi-level strategy, which helps to bridge the gap between detailed local process-oriented studies and global coverage by combining in situ measurements (mass balance, length change) with remote-sensing data and digital terrain information (areas, elevations, topographic parameters, inventories) and numerical modelling (thickness estimates, energy balance, flow modelling). The primary aim of this paper is to illustrate this concept by integrating a rich basis of existing data for the case of the European Alps, where especially dense information has been available through historical times. It thereby first (a) analyzes mass change through time at a sample of individual glaciers as a direct expression of changing energy and mass (precipitation) fluxes between the atmosphere and the Earth surface, and then (b) combines the corresponding results with overall changes in glacier area and volume for the entire mountain chain with a view to corresponding impacts on landscapes, the water cycle, geomorphic processes or natural hazards. The study refers to primary goals of long-term climaterelated monitoring programmes, i.e. early detection, model validation and assessing impacts of change. After a brief overview of the multi-level system as defined for GTN-G, examples relating to (a) and (b) as given above are presented, and finally current major challenges for an integrated global glacier monitoring strategy are discussed.

\section{THE MULTI-LEVEL SYSTEM FOR GTN-G}

The multi-level system as defined for GTN-G follows the global hierarchical observing strategy (GHOST) and was first described by Haeberli and others (2000). It attempts to connect intensive local studies on individual glaciers with coverage of large glacier ensembles at the global scale by integrating the following steps (see Haeberli, 2004, for a more detailed discussion):

extensive and process-oriented glacier mass-balance and flow studies within the major climatic zones for calibrating numerical models (there are about ten glaciers with intensive research and observation activities that represent such sites; Storglaciären, northern Sweden, is an example (Haeberli and others, 2005));

regional glacier mass changes within major mountain systems, observed with a limited number of strategically selected stakes/pits combined with precision mapping at about decadal intervals: on about 50 glaciers annual mass-balance studies reflect regional patterns of glacier mass changes (Haeberli and others, 2005); however, spatial coverage still shows gaps in some of the major mountain systems such as the Himalaya, the New Zealand Alps and Patagonia (Dyurgerov and Meier, 1997);

long-term observations of glacier length changes: a minimum of about ten sites within each major mountain range should be selected to represent different glacier sizes and dynamic responses; the representativeness of glaciers can be assessed by intercomparison (within and between regions) of geometrically comparable glaciers, dynamic fitting of glacier flow models to long time series of measured cumulative length change (Oerlemans and others, 1998), and mass-change reconstructions using concepts of mass conservation (Hoelzle and others, 2003); 
glacier inventories repeated at intervals of a few decades using satellite remote sensing (continuous upgrading and analyses of existing and newly available data; modelling of data following the scheme developed by Haeberli and Hoelzle (1995)).

Basic elements of these recommendations have been explained before (Haeberli and others, 1998) but still need further evaluation and testing. Strategically selected stakes/ pits (a minimum of three) for determining high-frequency (annual) mass change in connection with repeated mapping should, for instance, document (a) effects near the equilibrium line where the largest glacier areas tend to be and where mass-balance sensitivity is largely determined (Braithwaite, 2006); (b) the balance at the glacier terminus, which is used to convert cumulative long-term length change into average long-term mass change (Hoelzle and others, 2003); and herewith (c) the mass-balance gradient in the ablation area as the main expression of climate sensitivity and flow forcing (Dyurgerov and Dwyer, 2001). Long-term observations at isolated index stakes without repeated mapping of the entire glacier are not recommended, because they cannot easily be related to other components of the integrated monitoring strategy and may even be confusing for a wider public. Concerning length change, geometry largely determines dynamic response characteristics (Fig. 1) and is clearly more important than local neighbourhood: small, low-stress cirque glaciers ('glaciers réservoirs') react to high-frequency signals but with small overall length change; mountain glaciers with intermediate size on relatively steep slopes ('glaciers évacuateurs') filter out short-term climate influences but clearly show changes at decadal time intervals (e.g. in the Alps, the intermittent readvances and mass gains around 1920 and 1965-80); while long valley glaciers provide the strongest climate signals, but with a time resolution at the century scale. In general, glaciers with surge behaviour, calving instabilities or ablation by ice avalanching, but also glaciers subject to volcanic influences, heavily covered by debris or resting on thick sediment beds (causing corresponding longterm changes in bed level), are not suitable for climatic inferences. As an example for the European Alps, the long series of isolated local seasonal balance (accumulation) observations at two sites on Claridenfirn (starting in 1917) must be disregarded in this respect, as Claridenfirn is mostly an accumulation area with ice avalanches constituting the main ablation process, prohibiting geometric changes and, hence, making realistic mass-balance determinations impossible for simple topographic reasons.

Numerical modelling at various levels of complexity and remote-sensing information should help to extend the measured data in space and time, i.e. bridging the gap between local studies and global application. In this respect, there is a large potential for the use of modern geoinformatic techniques (i.e. geographic information systems (GIS)) that allow extraction of data and calculation of statistics for thousands of glacier entities automatically (Kääb and others, 2002; Paul and others, 2002; Paul, 2004). The suite of numerical models that can be applied reaches from (a) simple but robust parameterization schemes (Haeberli and Hoelzle, 1995; Hoelzle and others, 2007) to (b) more complex, physically based assessments (Hoelzle and others, 2003) to (c) distributed glacier energy-balance models of varying complexity (e.g. Oerlemans, 1992; Arnold and

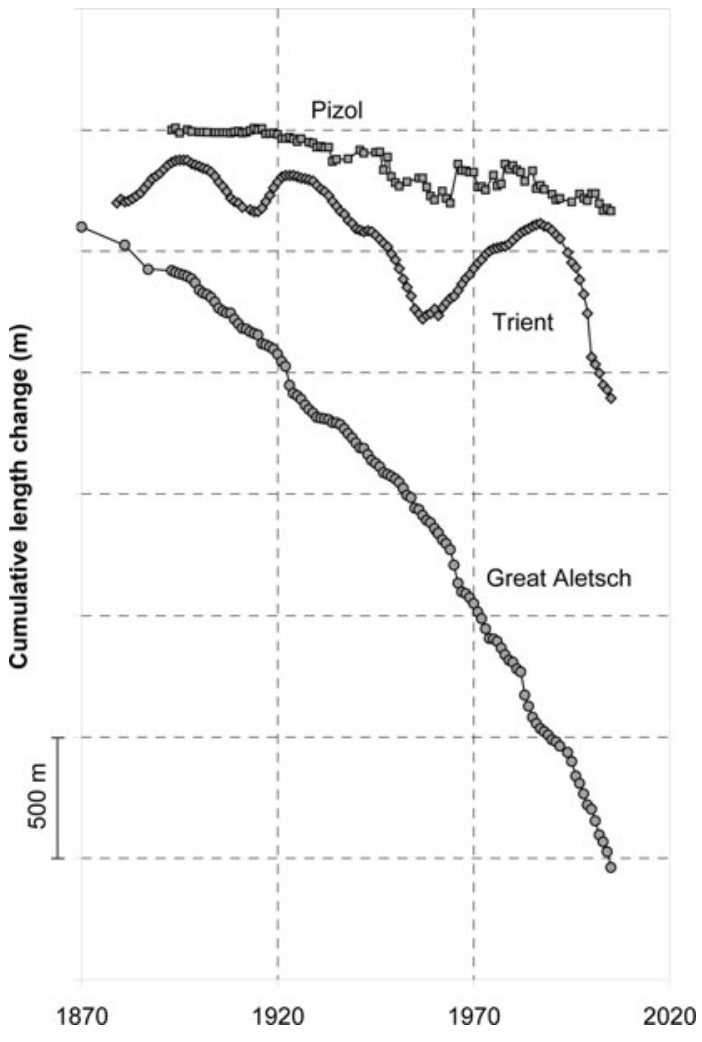

Fig. 1. Cumulative length changes since 1900 of three characteristic glacier types in the Swiss Alps. Small cirque glaciers such as Pizolgletscher have low basal shear stresses and directly respond to annual mass-balance and snowline variability through deposition/ melting of snow/firn at the glacier margin. Medium-sized mountain glaciers such as Glacier de Trient flow under high basal shear stresses and dynamically react to decadal mass-balance variations in a delayed and strongly smoothed manner. Large valley glaciers such as Aletschgletscher may be too long to dynamically react to decadal mass-balance variations, but exhibit strong signals of secular developments. Considering the whole spectrum of glacier response characteristics gives the best information on secular, decadal and annual developments. Data from WGMS.

others, 1996; Klok and Oerlemans, 2002; Machguth and others, 2006b) and to (d) coupled mass-balance-glacier-flow models (e.g. Greuell, 1992; Oerlemans, 1997; Hubbard and others, 2000). In particular, (c) has the potential to calculate climate-change effects on mountain glaciers from (downscaled) meteorological data as computed by regional climate models (RCMs) and other gridded input datasets (Paul and others, 2006; cf. Salzmann and others, 2007, for analogous permafrost modelling). The following illustrates various methods of assessing past, current and future glacier mass changes by combining field data and/or remotesensing information with numerical modelling. Such approaches build on a robust understanding of some of the most fundamental aspects related to the process chain linking climate and (medium-sized mountain) glaciers:

air temperature predominates in the temporal variability of the energy balance (e.g. Braithwaite 2006; Braithwaite and Raper, 2007; and references therein) and causes mass balances to be spatially correlated over large regions (spanning several hundred kilometres: Letréguilly and Reynaud, 1990; Cogley and Adams, 1998), an effect which is most likely due to combined influences from sensible-heat and longwave radiation (Ohmura, 2001); 
Table 1. Geodetically/photogrammetrically determined secular mass balances of alpine glaciers

\begin{tabular}{|c|c|c|c|c|c|}
\hline Glacier & Observation period & Location & $\begin{array}{c}\text { Median elevation } \\
\text { ma.s.l. }\end{array}$ & $\begin{array}{c}\text { Surface area } \\
\mathrm{km}^{2}\end{array}$ & $\begin{array}{c}\text { Mass balance } \\
\text { m w.e. } \mathrm{a}^{-1}\end{array}$ \\
\hline Rhone & 1882-1987 & $46^{\circ} 37^{\prime} \mathrm{N}, 08^{\circ} 24^{\prime} \mathrm{E}$ & 2940 & 17.38 & -0.25 \\
\hline Vernagt & 1889-1979 & $46^{\circ} 53^{\prime} \mathrm{N}, 10^{\circ} 49^{\prime} \mathrm{E}$ & 3228 & 9.55 & -0.19 \\
\hline Guslar & 1889-1979 & $46^{\circ} 51^{\prime} \mathrm{N}, 10^{\circ} 48^{\prime} \mathrm{E}$ & 3143 & 3.01 & -0.26 \\
\hline Schnee north & 1892-1979 & $47^{\circ} 25^{\prime} \mathrm{N}, 10^{\circ} 59^{\prime} \mathrm{E}$ & 2690 & 0.39 & -0.35 \\
\hline Schnee south & 1892-1979 & $47^{\circ} 24^{\prime} \mathrm{N}, 10^{\circ} 58^{\prime} \mathrm{E}$ & 2604 & 0.18 & -0.57 \\
\hline Hintereisferner & 1894-1979 & $46^{\circ} 48^{\prime} \mathrm{N}, 10^{\circ} 46^{\prime} \mathrm{E}$ & 3050 & 9.70 & -0.41 \\
\hline
\end{tabular}

Sources: Finsterwalder and Rentsch (1981); Haeberli and Müller (1988); Chen and Funk (1990).

patterns of long-term precipitation have a strong influence on glacier variability in space (mass turnover, englacial temperatures, relation to periglacial permafrost, mass-balance sensitivity: e.g. Oerlemans, 2001; Haeberli and Burn, 2002; Braithwaite, 2006) but change rather weakly in time (over decadal to centennial periods) and hence appear to have only secondary effects with respect to recent glacier fluctuations (e.g. Oerlemans, 2005; Schöner and Böhm, 2007);

dynamic response times for complete adjustment to equilibrium conditions are slope-dependent, for the simple reason that they depend on ice thickness divided by the balance at the terminus (Jóhannesson and others, 1989) and the balance at the terminus (in steady-state condition) tends towards zero with slope decreasing towards zero (Haeberli and Hoelzle, 1995); characteristic values are on the order of decades for typical (relatively thin and steep) mountain glaciers but may reach centuries for large (thick), flat glaciers;

geometric changes over such time intervals are primarily governed by mass conservation (Greuell, 1992; Boudreaux and Raymond, 1997; Hoelzle and others, 2003) rather than by specific aspects of glacier flow;

albedo and mass-balance/altitude feedbacks can have strong impacts (Paul and others, 2005; Raymond and Neumann, 2005) and may even cause self-reinforcing 'runaway effects' (downwasting rather than retreat of glaciers where 'vertical' thickness loss is faster than the capacity of a glacier to 'horizontally' retreat); increasing debris cover, on the other hand, tends to decouple glaciers from atmospheric influences and can markedly slow down ice melting and strongly retard tongue retreat (Smiraglia and others, 2000). Sometimes, debris-covered glacier tongues may even lose contact with the main glacier and develop into a body of 'dead ice'. Lengthchange measurements make little sense in such cases.

\section{MASS CHANGE THROUGH TIME AT INDIVIDUAL GLACIERS}

\subsection{Mass-balance measurements}

Mass-balance measurements in GTN-G combine the direct glaciological method (stakes and pits: point measurements with high time resolution) with the photogrammetric/ geodetic method (repeated mapping: survey of the entire glacier at lower time resolution) for optimal information and calibration. Field measurements are either carried out with extended stake/pit networks for detailed process understanding and development of numerical models, or use costsaving approaches with reduced numbers of strategically chosen 'index' stakes, providing gross regional indications of change (Haeberli and others, 1998).

Photogrammetrically/geodetically determined volume changes and glacier mass balances are available in the European Alps back to the late 19th century (Table 1). Uninterrupted in situ measurements since 1967 of mass balance at nine Alpine glaciers are shown in Figure 2. Near-equilibrium conditions until 1981 were followed by very strong and continued if not accelerating mass loss $\left(0.7 \mathrm{mw}\right.$. e. $\mathrm{a}^{-1}$; trend of increase in mass loss $0.03-$ $0.04 \mathrm{~m}$ w.e. $\mathrm{a}^{-2}$ ). During the first 5 years of the 21 st century, mean annual mass losses have been close to $1 \mathrm{~m}$ w.e. $\mathrm{a}^{-1}$. The hot, dry summer of 2003 alone caused a record mean loss of $2.45 \mathrm{~m}$ w.e., roughly $50 \%$ above the previous record loss in 1998.

It must be kept in mind that climatic conditions which remain constant in time would lead to geometric adjustment of glaciers to new equilibrium states and a corresponding zero balance. Continued non-zero balances indicate ongoing climate forcing (assuming feedbacks from albedo, elevation change, debris cover or dry/wet calving do not affect mass balance for the considered glaciers), and increasing deviations from zero balances reflect accelerating change. True values for continued or accelerated forcing would have to be modelled for glacier areas remaining constant in time (cf. Elsberg and others, 2001; Harrison and others, 2005), an important future possibility for distributed energy- and mass-balance models.

\subsection{Mass-balance reconstructions}

Mass-balance values during earlier periods must be reconstructed. Models of variable complexity are available for this purpose. Information on cumulative glacier length changes thereby plays a key role for calibration and validation. For the time since the end of the Little Ice Age around 1850, reconstructions have been based on (a) a straightforward continuity consideration applied to cumulative length changes (Haeberli and Hoelzle, 1995; Hoelzle and others, 2003), and (b) neural networks using presentday mass-balance measurements together with meteorological data that reach farther back in time (Steiner and others, 2005). The two approaches are completely independent and both provide long-term mass-balance averages of -0.25 to -0.3 m w.e. $\mathrm{a}^{-1}$, i.e. three to four times less than the most recently observed values. The generally observed retreat of Alpine glacier tongues leaves no doubt that these 


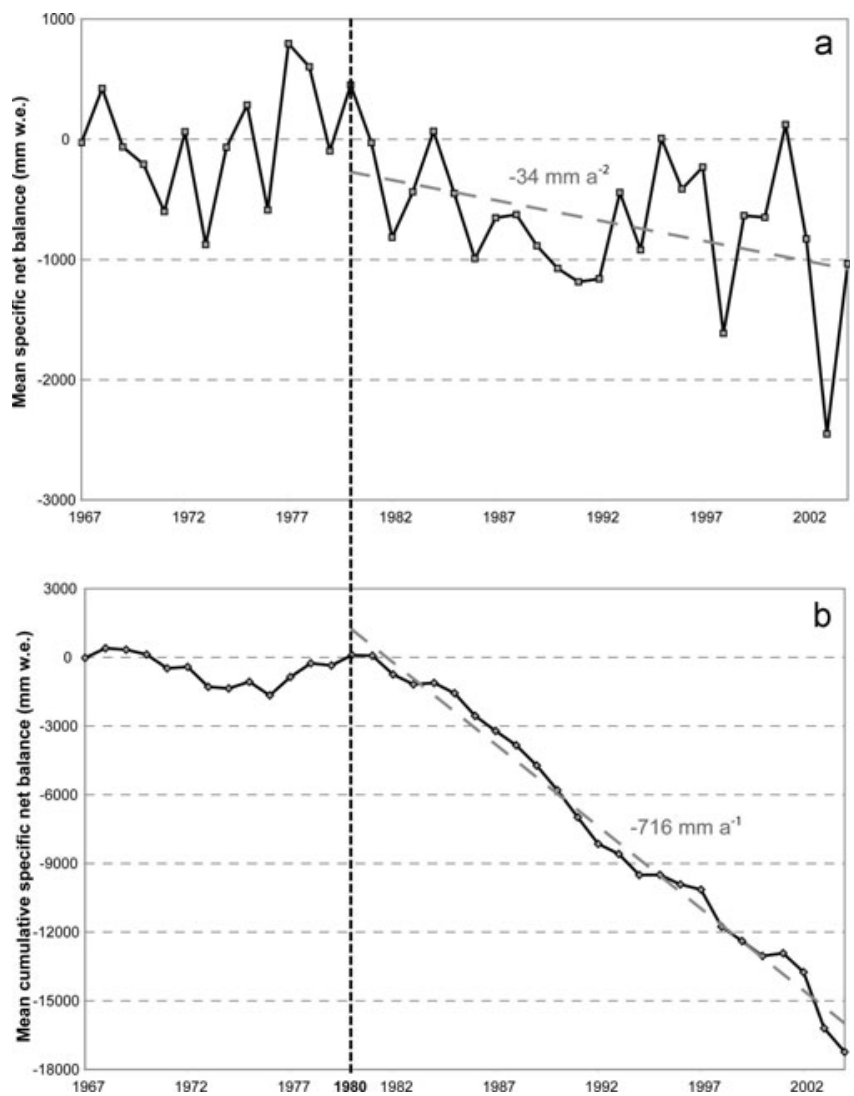

Fig. 2. Annual (a) and cumulative (b) mass balance of nine glaciers with uninterrupted mass-balance determination (for the entire glacier) in the European Alps (Saint-Sorlin and Sarennes, France; Gries and Silvretta, Switzerland; Careser, Italy; Hintereis, Kesselwand, Vernagt and Sonnblick, Austria). Data from WGMS. The light dashed lines show an average mass loss of nearly $18 \mathrm{~m}$, or $716 \mathrm{~mm} \mathrm{a}^{-1}$, (b) and an average increase in mass loss of $34 \mathrm{~mm} \mathrm{a}^{-2}$ (a) since 1980 . The Silvretta values may be systematically too positive and should be corrected in the near future.

secular trends and values are representative for the entire mountain chain. Backward reconstructions beyond the mid19th century are much less homogeneous, especially with respect to temporal changes. This effect so far remains unexplained, but may relate to the fact that statistical models are calibrated with direct measurements on glaciers of already reduced size but then extrapolated for periods with considerably larger glaciers and, most likely, different sensitivities and response characteristics.

The continuity approach (a) was also applied to longerterm cumulative length changes of Grosser Aletschgletscher, Switzerland, (Haeberli and Holzhauser, 2003) which was reconstructed in detail from historical documents, moraine dating and fossil trees for the past 3500 years (Holzhauser and others, 2005). Over the past two millennia, characteristic century to half-century mass-balance averages (mean \pm 0.3 and maximum $\pm 0.5 \mathrm{~m}$ w.e. $\mathrm{a}^{-1}$ ) are comparable to the loss rates since the Little Ice Age and they were far below those observed since 1981. In fact, the mass losses observed since the mid-1980s (about $0.75 \mathrm{mw}$.e. $\mathrm{a}^{-1}$ ) exceed the maximum, and even double the maximum, characteristic long-term loss rates during the past two millennia (Fig. 3). Such comparisons help to confirm the spatial representativeness of half-centennial to centennial mass-balance averages with their uncertainty range or variability in
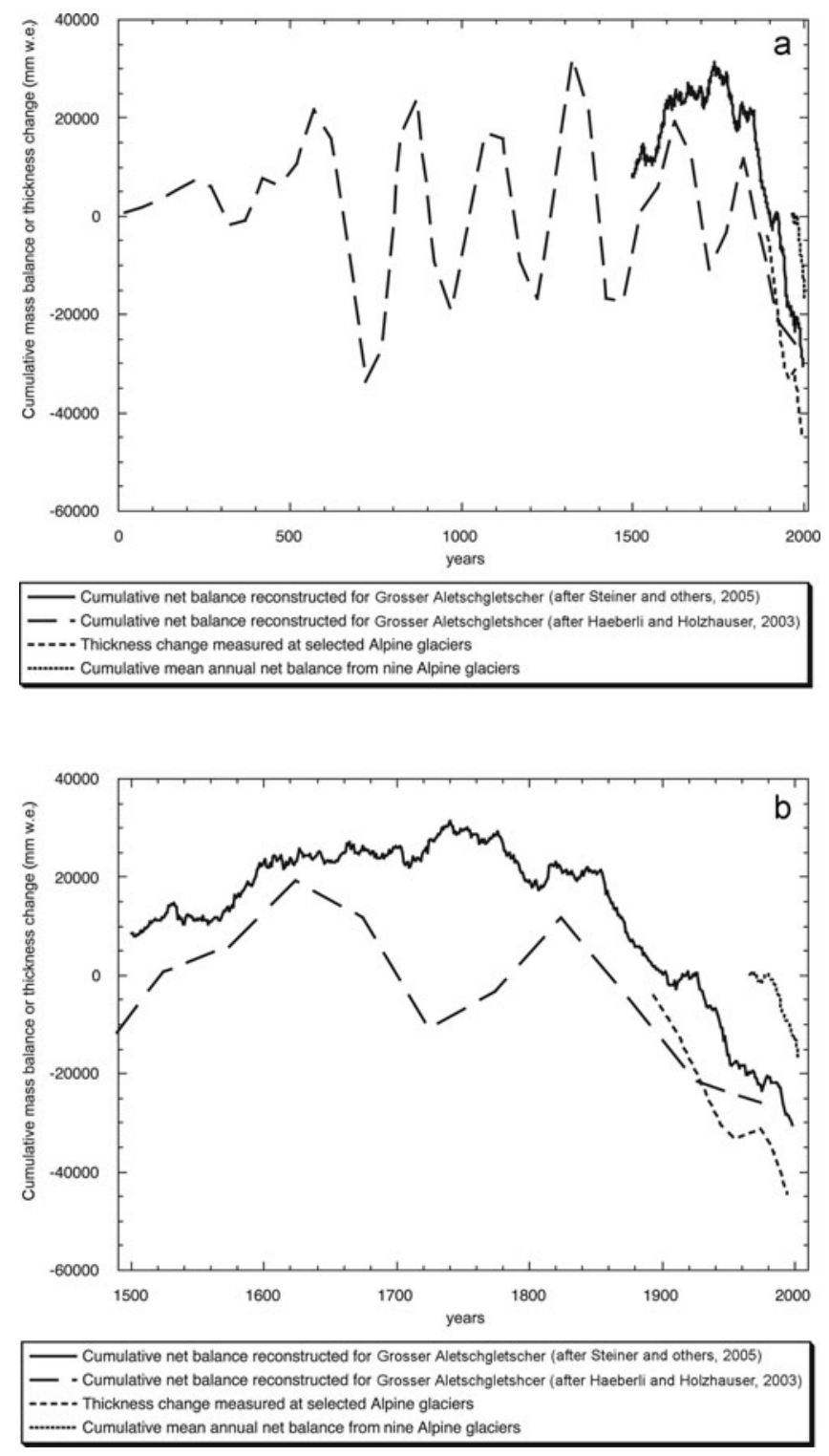

Fig. 3. Measured and reconstructed mass balances in the European Alps for (a) the past 2000 years and (b) the past 500 years. Data from WGMS (measured thickness change 1890-2000 and mass balance 1967-2004), Steiner and others (2005) (neural networks; last 500 years) and Haeberli and Holzhauser (2003) (continuity model; past two millennia); cf. also Tables 3 and 4 in the Appendix. The essential information on rates of mass change is reflected in the slopes of the curves; the vertical position of the curves is somewhat arbitrary.

sensitivity (roughly $\pm 50 \%$ of the calculated mean) as a function of individual glacier geometry (hypsography) and local to regional differentiation of climate forcing (Haeberli and Hoelzle, 1995; Hoelzle and others, 2003).

Distributed mass-balance models taking into account local effects such as those from topography, local albedo or snow redistribution by wind and avalanches not only narrow the uncertainty by providing safer estimates of ablation at glacier margins in complex topography, but also help to explain the variable climate sensitivity of individual glaciers (e.g. Klok and Oerlemans, 2002; Machguth and others, 2006b; Paul and others, in press). Realistic estimation of local precipitation and accumulation patterns (cf. Machguth and others, 2006a) thereby remains the primary challenge, influencing the results considerably more than the relatively 


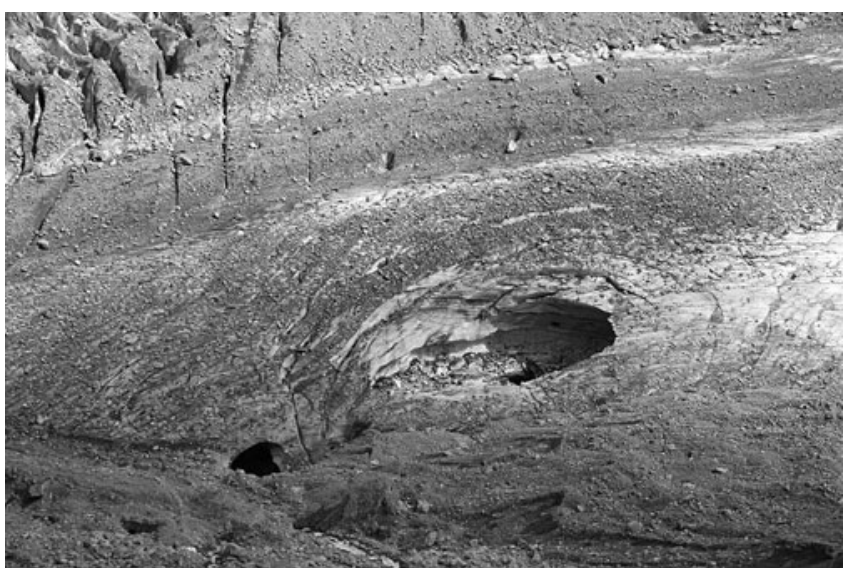

Fig. 4. Roseggletscher in the eastern Swiss Alps, with a collapse hole on its thin tongue. Photo by C. Rothenbühler, summer 2003.

well-established calculation of the summer energy balance and the resulting ablation patterns (e.g. Hock, 2005).

\subsection{Consequences of the recent mass loss}

The increasingly fast mass and 'vertical' thickness loss clearly points to an accelerating trend in climatic forcing. The corresponding additional energy flux calculated as the latent heat of the disappearing ice (around $10 \mathrm{~W} \mathrm{~m}^{-2}$ as an average of the past 5 years) is about twice the estimated present-day radiative forcing alone (several $\mathrm{W} \mathrm{m}^{-2}$; Wild and others 2005) and most probably relates to important feedback mechanisms. The albedo feedback from disappearing firn in former accumulation areas has long-term consequences: the extreme summer 2003 essentially eliminated all remaining firn from the surface of many smaller and medium-sized glaciers. In addition, these bare surfaces strikingly darkened because of wind-blown dust from the snow-free and dry mountains around. As a consequence, the melting snow cover in springtime now uncovers a lowalbedo surface, which suffers from strongly enhanced melt (Paul and others, 2005).

Rapid thickness loss with limited tongue retreat also reduces driving stresses and flow within the ice. In such a situation, effects from mass-balance/altitude feedback become fundamentally important, especially for large, thick glaciers which cannot lose exposed ablation areas fast enough. Thereby, total surface lowering (integrated over time) must be compared with the mass-balance/altitude gradient. Due to glacier dynamics, local surface lowering can be considerably more rapid than local ablation (negative mass balance) alone; it represents a cumulative phenomenon which can lead to irreversible runaway effects ('downwasting' or even 'collapse' rather than 'retreat'). Observed and reconstructed mass losses are therefore also a function of glacier size (Hoelzle and others, 2003), with large glaciers reducing their thickness more rapidly than small ones. Morphological phenomena of downwasting (flat longitudinal and concave transversal surface profiles, abundant debris cover, collapse holes above subglacial drainage channels, lake formation) have now become visible on many glacier tongues (Fig. 4). With continued thickness losses of $1 \mathrm{~m}$ w.e. $\mathrm{a}^{-1}$ or even more, the glaciers with longterm mass-balance time series may disappear within a few decades from now (cf. the experiments with distributed modelling of equilibrium-line altitudes by Zemp and others
Table 2. Estimated ice volumes in 1850, 1975, 2000 and 2005, and changes in the European Alps. The increase in volume-change rates indicates continued or even enhanced climate forcing, but might also be influenced by the different lengths of the periods considered. Data from Zemp and others (2006)

\begin{tabular}{|c|c|c|c|c|}
\hline & 1850 & 1975 & 2000 & 2005 \\
\hline Volume $\left(\mathrm{km}^{3}\right)$ & 200 & 105 & 75 & 65 \\
\hline Relative volume change (\%) & -47.5 & -28.5 & & \\
\hline Change rate $\left(\%\right.$ decade $\left.^{-1}\right)$ & -3.8 & -11.4 & & \\
\hline
\end{tabular}

(2006, 2007) or with dynamically fitted mass-balance/flow models by Oerlemans and others, 1998). This constitutes a serious challenge for long-term monitoring programmes (Paul and others, 2007b).

\section{CHANGES IN TOTAL ALPINE GLACIER COVER}

\subsection{Assessment of total glacier volume}

With the compilation of glacier inventories, treatment of entire mountain ranges became possible by combining time series measured at selected glaciers with statistical information on the whole glacier ensemble at suitable time slices. The first calculations for the European Alps as a pilot study for worldwide applications have already indicated the dramatic overall loss in glacier cover for the past century and even more so for realistic scenarios of atmospheric temperature rise during the 21st century (Haeberli and Hoelzle, 1995). A primary challenge with such efforts is the realistic estimation of glacier thickness and corresponding ice volumes. The often-used volume/area scaling (Bahr and others, 1997) is problematic, as it correlates a statistical variable (area) with itself (area in volume) and, hence, suppresses the large scatter (roughly $30 \%$ standard deviation for mountain glaciers) in area/thickness relations, which are statistically more reasonable.

A more process-oriented approach applies geometrydependent driving stresses in combination with mass turnover as defined by the mass-balance gradient and the altitudinal extent of glaciers (Haeberli and Hoelzle, 1995). An even simpler and astonishingly elegant consideration assumes that relative volume change is closely comparable to relative area change, because mean glacier thickness (averaged for the changing glacier area) tends to remain constant (even with pronounced overall changes in glacier mass!): by calculating total volume loss from mass-balance time series and mean area during the investigated time interval, and by assuming that percentages in area loss correspond to percentages in volume loss, total volume can be directly approximated (Paul and others, 2004). Results for the total glacier volume in the Alps from the three approaches differ by about $\pm 20 \%$ around a mean $\left(100-140 \mathrm{~km}^{3}\right.$ for the 1970s; Zemp and others, 2006), but have their specific advantages: the area/thickness relation is the easiest to apply; the driving-stress solution enables the best understanding of individual thickness variability; while the 'area-volume percentage' solution may provide the safest overall estimate.

\subsection{Calculation of ongoing volume changes}

Best estimates for total volumes and volume changes (Table 2; cf. Haeberli and others, 2004; Paul and others, 


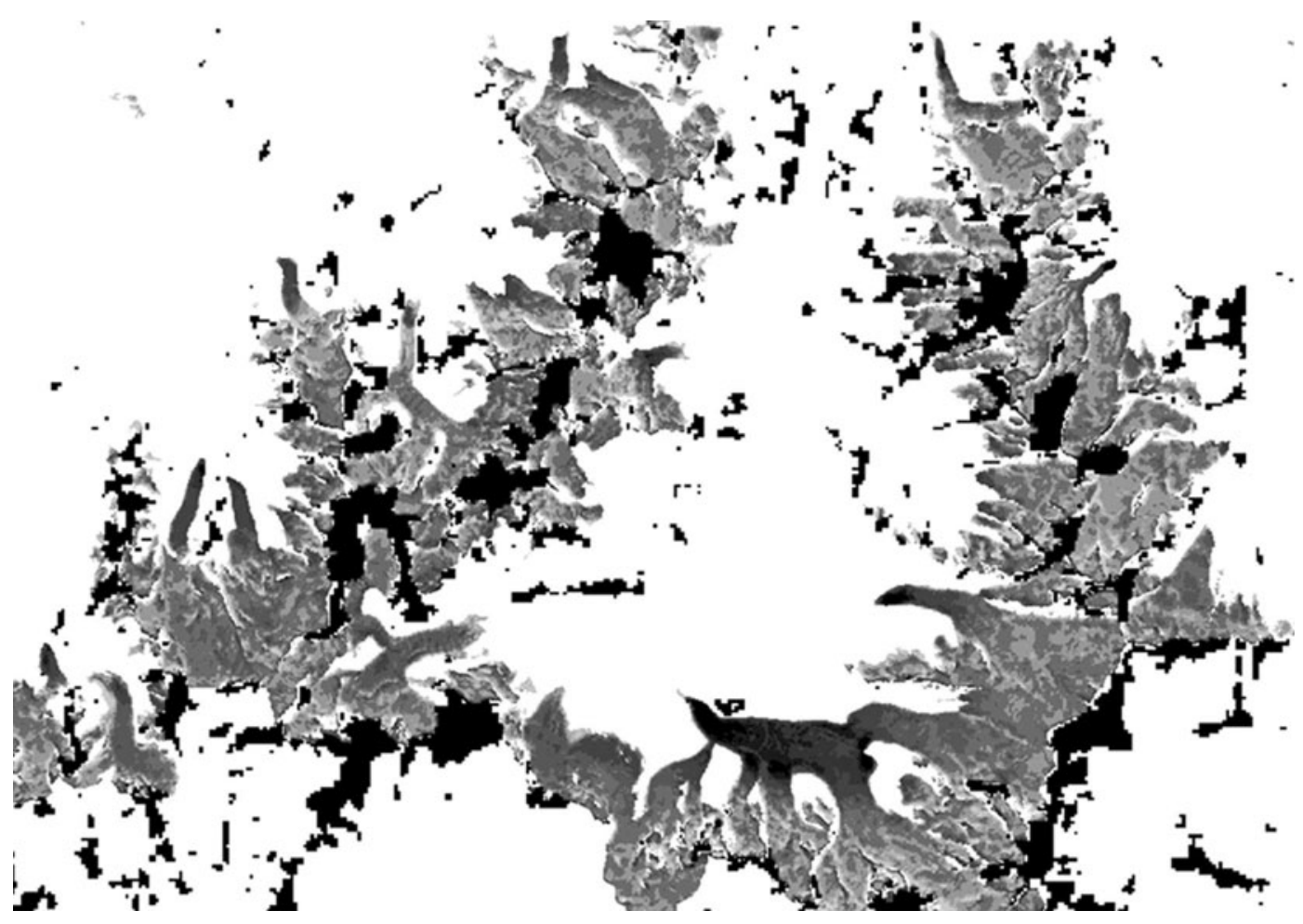

Fig. 5. Changes in glacier elevation in the region of Zermatt, Swiss Alps, with Gomergletscher at the lower right, from differencing the SRTM3 DEM (resampled to $25 \mathrm{~m}$ ) from the year 2000 and the swisstopo DEM25 L1 from about 1985. Irregular black areas indicate data voids in the SRTM DEM, which are usually located outside the glacier perimeter. The grey values denote elevation changes from $-80 \mathrm{~m}$ (darkest grey value) to $+10 \mathrm{~m}$ (brightest grey value) and are plotted in classes of half standard deviations. North is at top and image width is $38 \mathrm{~km}$.

2004; Zemp and others, 2006) show that glaciers in the European Alps lost about half their total volume (roughly $0.5 \% \mathrm{a}^{-1}$ ) between 1850 and around 1975, another $25 \%$ $\left(1 \% \mathrm{a}^{-1}\right)$ of the remaining amount between 1975 and 2000, and an additional $10-15 \%\left(2-3 \% \mathrm{a}^{-1}\right)$ in the first 5 years of this century. The latter estimate is obtained from the mean value of the mass-balance observations at nine Alpine glaciers in combination with the new satellite-derived glacier areas from 1998/99 (Paul, 2004) and a simple model of calculating total glacier volume from mean thickness (Maisch and others, 2000).

Completely new perspectives are coming up with repeated satellite-derived digital terrain models. Even though problems of resolution and accuracy must be carefully evaluated (Berthier and others, 2006), relative changes as an expression of variable sensitivities can be investigated and used to assess how representative massbalance time series from selected glaciers are and how they can be best extrapolated to the entire mountain range. Preliminary results from the Swiss Alps indicate a trend towards more negative balances on large, flat glaciers than on smaller ones (Fig. 5).

\subsection{Calculation of potential future changes}

Extrapolation for the future based on scenarios of atmospheric warming and relations between mass balance and temperature/precipitation at the equilibrium-line altitude (ELA) as calibrated with long-term mass-balance measurements and gridded climatologies leave no doubt that in such climate scenarios most of the glacier cover in the European Alps is likely to disappear within decades (Zemp and others, 2006, 2007).
Modern data from satellite images as combined with digital terrain information (Kääb and others, 2002; Paul and others, 2002, 2007a) greatly enhance the possibilities for numerical modelling and visualization of large samples. Figure 6 is an attempt to combine hypsographic modelling with digital glacier outlines, a satellite image and a digital elevation model (DEM) to visualize a likely sequence of individual glacier decay for a larger region within the Alps. Thereby, simple geometrical rules like a steady-state accumulation-area ratio (AAR) of 0.6 and parameterizations of the ELA sensitivity to temperature change are assumed (Paul and others, 2007a). Such dramatic changes will have strong and predominantly negative impacts on landscape evolution, water supply, erosion/sedimentation, slope stability and natural hazards. Monitoring and spatio-temporal modelling of glacier changes must help with anticipating and mitigating the consequences of such extreme deviations from our historical-empirical knowledge basis and from Holocene conditions of dynamic equilibria.

\section{PERSPECTIVES AND FUTURE TASKS}

Several further applications of the multi-level glacier monitoring strategy can be envisaged for the future:

Validation of length change measurements over longer periods from comparisons with satellite data and the related extension of the currently annually measured sample to other remote but climatically interesting regions which are still underrepresented in the existing observational network (e.g. Patagonia and Tierra del Fuego; central Asian high mountains; New Zealand; or 


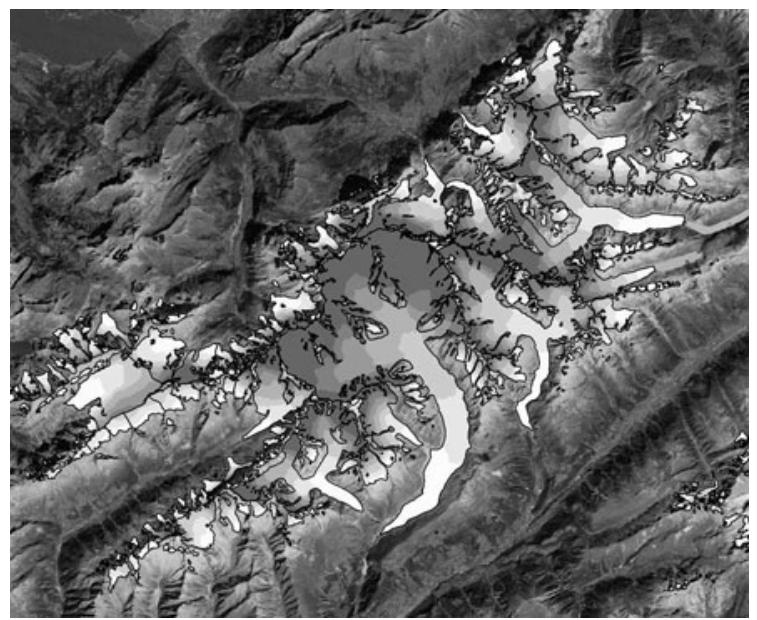

Fig. 6. Glacier extent for the Aletsch region in 1973 (black outlines) and modelled extent for six shifts of the steady-state ELA using an AAR of 0.6. The legend gives the greyscale that will disappear due to the corresponding shift in ELA. For an ELA rise of $600 \mathrm{~m}$, only the darkest regions will remain. The background is a Landsat satellite image acquired at 31 August 1998. Landsat data (C) Eurimage/Swiss National Point of Contact for Satellite Images (NPOC).

the glaciers around Greenland and on Arctic islands (Paul and Kääb, 2005)). This would also allow a rough first-order estimate of the related long-term mass changes in such regions (cf. Hoelzle and others, 2003, 2007).

Assessment of firn lines from (maybe annual) satellite data (e.g Rabatel and others, 2005) over large areas, and calculation of the related glacier mass balance by comparison with results from distributed mass-balance models.

Application of such distributed mass-balance models over entire mountain ranges (Machguth and others, 2006a; Paul and others, in press) by incorporating extrapolated and gridded datasets of the required input parameters (e.g. precipitation, albedo, potential global radiation) for solving the problems in the accumulation area, which are not obvious if only glacier melt is calculated and models are applied to (e.g. Arnold and others, 1996; Brock and others, 2000) or tuned for individual glaciers (e.g. Klok and Oerlemans, 2002).

Extrapolation of mass-balance measurements at individual ablation stakes and snow pits from such distributed models instead of the simple regressions applied today could presumably help to obtain more realistic mass-balance profiles, as local topographic variability could be much better taken into account (e.g. Arnold and others, 2006).

Direct use of output from regional climate models (after appropriate downscaling) to run mass-balance models instead of the sensitivity studies usually applied. This would help to assess the impacts of future climate change (including a changed variability) much more realistically (Paul and others, 2006).

The approaches and examples presented here demonstrate the large potential of assessing climate-change effects on entire mountain ranges by combining field data with remotesensing information and numerical modelling. Therefore, two of the most important tasks are the compilation of digital glacier outlines and DEM data at appropriate spatial resolution and on a global scale. While for the latter the near-global availability of the $\sim 90 \mathrm{~m}(30 \mathrm{~m}$ in the US) resolution Shuttle Radar Topography Mission (SRTM) DEM (e.g. Rabus and others, 2003) is a huge step forward (if not a quantum leap), the compilation of digital glacier outlines from remote-sensing data (or digitizing of former inventories) is still in its early stages. The GLIMS project (e.g. Bishop and others, 2004; Kargel and others, 2005) certainly marks an important starting point, but, due to the small swath width of the Advanced Spaceborne Thermal Emission and Reflection Radiometer (ASTER) sensor (i.e. one-ninth of the Landsat Thematic Mapper (TM)/Enhanced Thematic Mapper Plus $(\mathrm{ETM}+))$, compilation of the data over larger glacierized regions with frequent cloud cover (Himalaya, Canadian Arctic Archipelago, Alaska, etc.) will take additional time. This time should be utilized to communicate about, and finally agree on, standards for glacier definition that support the glacier delineation process, especially with respect to problems in the accumulation area (contributing slopes and hanging glaciers), near flat firn divides or with glaciers splitting up when decaying and retreating, but are still commensurable with existing standards in order to enable comparison with earlier inventories.

\section{CONCLUSIONS}

Integrated use of long-term in situ measurements, satellite images, digital terrain information and numerical models enables overall as well as locally differentiated assessments of ongoing climate-change effects on glacier covers of entire mountain ranges. The mass and volume losses of glaciers in the European Alps are not only fast but seem to be clearly accelerating. This acceleration trend is not only due to accelerated climatic forcing but includes strongly reinforcing feedback mechanisms (albedo, mass balance/altitude) and could lead to near-complete deglaciation of the Alps during the coming decades and the present century. High priority for future research should be given to similar assessments concerning other mountain regions with less dense data and/or shorter time series, and to assessing environmental consequences of such dramatic deviations from past conditions and near-equilibrium states.

\section{ACKNOWLEDGEMENTS}

This study is funded mainly by the Swiss Federal Office of Education and Science (BBW-Contract 901.0498-2) within the European Union programme ALP-IMP (contract EVK2CT-2002-00148). D. Steiner kindly provided the Aletsch mass-balance data as reconstructed using neural networks. B. Brock, C. Stokes, R. Braithwaite and an anonymous reviewer provided constructive comments which helped improve the paper. We thank the national correspondents and principal investigators of the WGMS for collection and free exchange of important data over many years.

\section{REFERENCES}

Arnold, N.S., I.C. Willis, M.J. Sharp, K.S. Richards and W.J. Lawson. 1996. A distributed surface energy-balance model for a small valley glacier. I. Development and testing for Haut Glacier d'Arolla, Valais, Switzerland. J. Glaciol., 42(140), 77-89. 
Arnold, N.S., W.G. Rees, A.J. Hodson and J. Kohler. 2006. Topographic controls on the surface energy balance of a high Arctic valley glacier. J. Geophys. Res., 111(F2), F02011. (10.1029/2005JF000426.)

Bahr, D.B., M.F. Meier and S.D. Peckham. 1997. The physical basis of glacier volume-area scaling. J. Geophys. Res., 102(B9), 20,355-20,362.

Bamber, J. 2006. Remote sensing in glaciology. In Knight, P.G., ed. Glacier science and environmental change. Oxford, etc., Blackwell Publishing, 370-382.

Berthier, E., Y. Arnaud, C. Vincent and F. Rémy. 2006. Biases of SRTM in high-mountain areas: implications for the monitoring of glacier volume changes. Geophys. Res. Lett., 33(8), L08502. (10.1029/2006GL025862.)

Bishop, M.P. and 16 others. 2004. Global land ice measurements from space (GLIMS): remote sensing and GIS investigations of the Earth's cryosphere. Geocarto Int., 19(2), 57-84.

Boudreaux, A. and C. Raymond. 1997. Geometry response of glaciers to changes in spatial pattern of mass balance. Ann. Glaciol., 25, 407-411.

Braithwaite, R. 2006. Measuring and modelling the mass balance of glaciers for global change. In Knight, P.G., ed. Glacier science and environmental change. Oxford, etc., Blackwell Publishing, 418-423.

Braithwaite, R.J. and S.C.B. Raper. 2007. Glaciological conditions in seven contrasting regions estimated with the degree-day model. Ann. Glaciol., 46 (see paper in this volume).

Brock, B.W., I.C. Willis, M.J. Sharp and N.S. Arnold. 2000. Modelling seasonal and spatial variations in the surface energy balance of Haut Glacier d'Arolla, Switzerland. Ann. Glaciol., 31, 53-62.

Chen, J. and M. Funk. 1990. Mass balance of Rhonegletscher during 1882/83-1986/87. J. Glaciol., 36(123), 199-209.

Cogley, J.G. and W.P. Adams. 1998. Mass balance of glaciers other than the ice sheets. J. Glaciol., 44(147), 315-325.

Dyurgerov, M. and J. Dwyer. 2001. The steepening of glacier mass balance gradients with Northern Hemisphere warming. Z. Gletscherkd. Glazialgeol., 36(1-2), 107-117.

Dyurgerov, M.B. and M.F. Meier. 1997. Mass balance of mountain and subpolar glaciers: a new global assessment for 1961-1990. Arct. Alp. Res., 29(4), 379-391.

Elsberg, D.H., W.D. Harrison, K.A. Echelmeyer and R.M. Krimmel. 2001. Quantifying the effects of climate and surface change on glacier mass balance. J. Glaciol., 47(159), 649-658.

Finsterwalder, R. and H. Rentsch. 1981. Zur Höhenänderung von Ostalpengletschern im Zeitraum 1969-1979. Z. Gletscherkd. Glazialgeol., 16(1), 111-115.

Global Climate Observing System (GCOS). 2003. The second report on the adequacy of the Global Observing Systems for Climate in support of the UNFCCC. Geneva, World Meteorological Organization. (GCOS-82.) (WMO/TD No. 1143.)

Global Climate Observing System (GCOS). 2004. Implementation plan for the Global Observing System for Climate in support of the UNFCCC. Geneva, World Meteorological Organization. (GCOS-92.) (WMO/TD No. 1219.)

Greuell, W. 1992. Hintereisferner, Austria: mass-balance reconstruction and numerical modelling of the historical length variations. J. Glaciol., 38(129), 233-244.

Haeberli, W. 2004. Glaciers and ice caps: historical background and strategies of worldwide monitoring. In Bamber, J.L. and A.J. Payne, eds. Mass balance of the cryosphere. Cambridge, etc., Cambridge University Press, 559-578.

Haeberli, W. and C. Burn. 2002. Natural hazards in forests: glacier and permafrost effects as related to climate change. In Sidle, R.C., ed. Environmental change and geomorphic hazards in forests. Wallingford, Oxon., CABI Publishing, 167-202.

Haeberli, W. and M. Hoelzle. 1995. Application of inventory data for estimating characteristics of and regional climate-change effects on mountain glaciers: a pilot study with the European Alps. Ann. Glaciol., 21, 206-212.
Haeberli, W. and H. Holzhauser. 2003. Alpine glacier mass changes during the past two millennia. PAGES News, 11(1), 13-15.

Haeberli, W. and P. Müller, eds. 1988. Fluctuations of glaciers 1980-1985 (Vol. V). Wallingford, Oxon, IAHS Press; Nairobi, UNEP; Paris, UNESCO.

Haeberli, W., M. Hoelzle and S. Suter, eds. 1998. Into the second century of world-wide glacier monitoring: prospects and strategies. A contribution to the International Hydrological Programme (IHP) and the Global Environment Monitoring System (GEMS). Paris, UNESCO. (Studies and Reports in Hydrology 56.)

Haeberli, W., J. Cihlar and R.G. Barry. 2000. Glacier monitoring within the Global Climate Observing System. Ann. Glaciol., 31, 241-246.

Haeberli, W. and 7 others. 2004. Effects of the extreme summer 2003 on glaciers and permafrost in the Alps - first impressions and estimations. Geophys. Res. Abstr. 6, 03063. (1607-7962/gra/ EGU04-A-03063.)

Haeberli, W., J. Noetzli, M. Zemp, S. Baumann, R. Frauenfelder and M. Hoelzle, eds. 2005. Glacier Mass Balance Bulletin No. 8 (2002-2003). Zürich, IAHS (ICSI), World Glacier Monitoring Service; Nairobi, UNEP; Paris, UNESCO.

Harrison, W.D., D.H. Elsberg, L.H. Cox and R.S. March. 2005. Correspondence. Different mass balances for climatic and hydrologic applications. J. Glaciol., 51(172), 176.

Hock, R. 2005. Glacier melt: a review on processes and their modelling. Progr. Phys. Geogr., 29(3), 362-391.

Hoelzle, M., W. Haeberli, M. Dischl and W. Peschke. 2003. Secular glacier mass balances derived from cumulative glacier length changes. Global Planet. Change, 36(4), 295-306.

Hoelzle, M., T. Chinn, D. Stumm, F. Paul, M. Zemp and W. Haeberli. 2007. The application of glacier inventory data for estimating past climate change effects on mountain glaciers: a comparison between the European Alps and the Southern Alps of New Zealand. Global Planet. Change, 56(1-2), 69-82.

Holzhauser, H., M. Magny and H.J. Zumbuhl. 2005. Glacier and lake-level variations in west-central Europe over the last 3500 years. Holocene, 15(6), 789-801.

Houghton, J.T. and 7 others. 2001. Climate change 2001: the scientific basis. Contribution of Working Group I to the Third Assessment Report of the Intergovernmental Panel on Climate Change. Cambridge, etc., Cambridge University Press.

Hubbard, A. and 6 others. 2000. Glacier mass-balance determination by remote sensing and high-resolution modelling. J. Glaciol., 46(154), 491-498.

Jóhannesson, T., C. Raymond and E. Waddington. 1989. Time-scale for adjustment of glaciers to changes in mass balance. J. Glaciol., 35(121), 355-369.

Kääb, A. 2006. The global land ice measurements from space (GLIMS) project. In Knight, P.G., ed. Glacier science and environmental change. Oxford, etc., Blackwell Publishing, 430-432.

Kääb, A., F. Paul, M. Maisch, M. Hoelzle and W. Haeberli. 2002. The new remote-sensing-derived Swiss glacier inventory: II. First results. Ann. Glaciol., 34, 362-366.

Kargel, J.S. and 16 others. 2005. Multispectral imaging contributions to global land ice measurements from space. Remote Sens. Environ., 99(1-2), 187-219.

Klok, E.J. and J. Oerlemans. 2002. Model study of the spatial distribution of the energy and mass balance of Morteratschgletscher, Switzerland. J. Glaciol., 48(163), 505-518.

Letréguilly, A. and L. Reynaud. 1990. Space and time distribution of glacier mass-balance in the Northern Hemisphere. Arct. Alp. Res., 22(1), 43-50.

Machguth, H., F. Paul, M. Hoelzle and W. Haeberli. 2006a. Distributed glacier mass-balance modelling as an important component of modern multi-level glacier monitoring. Ann. Glaciol., 43, 335-343. 
Machguth, H., O. Eisen, F. Paul and M. Hoelzle. 2006b. Strong spatial variability of snow accumulation observed with helicopter-borne GPR on two adjacent Alpine glaciers. Geophys. Res. Lett., 33(L13), L13503. (10.1029/2006GL026576.)

Maisch, M., A. Wipf, B. Denneler, J. Battaglia and C. Benz. 2000. Die Gletscher der Schweizer Alpen: Gletscherschwund 1850, Aktuelle Vergletscherung, Gletscherschwund-Szenarien 21. Jahrhundert. Zürich, vdf Hochschulverlag AG ETH Zürich. (Schlussbericht NFP 31.)

Oerlemans, J. 1992. Climate sensitivity of glaciers in southern Norway: application of an energy-balance model to Nigardsbreen, Hellstugubreen and Alfotbreen. J. Glaciol., 38(129), 223-232.

Oerlemans, J. 1997. Climate sensitivity of Franz Josef Glacier, New Zealand, as revealed by numerical modeling. Arct. Alp. Res., 29(2), 233-239.

Oerlemans, J. 2001. Glaciers and climate change. Lisse, etc., A.A. Balkema.

Oerlemans, J. 2005. Extracting a climate signal from 169 glacier records. Science, 308(5722), 675-677.

Oerlemans, J. and 10 others. 1998. Modelling the response of glaciers to climate warming. Climate Dyn., 14(4), 267-274.

Ohmura, A. 2001. Physical basis for the temperature-based meltindex method. J. Appl. Meteorol., 40(4), 753-761.

Paul, F. 2004. The new Swiss glacier inventory 2000: application of remote sensing and GIS. (PhD thesis, University of Zürich.)

Paul, F. and A. Kääb. 2005. Perspectives on the production of a glacier inventory from multispectral satellite data in Arctic Canada: Cumberland Peninsula, Baffin Island. Ann. Glaciol., 42, 59-66.

Paul, F., A. Kääb, M. Maisch, T. Kellenberger and W. Haeberli. 2002. The new remote-sensing-derived Swiss glacier inventory. I. Methods. Ann. Glaciol., 34, 355-361.

Paul, F., A. Kääb, M. Maisch, T. Kellenberger and W. Haeberli. 2004. Rapid disintegration of Alpine glaciers observed with satellite data. Geophys. Res. Lett., 31(L21), L21402. (10.1029/ 2004GL020816.)

Paul, F., H. Machguth and A. Kääb. 2005. On the impact of glacier albedo under conditions of extreme glacier melt: the summer of 2003 in the Alps. EARSeL eProc., 4(2), 139-149.

Paul, F., S. Kotlarski and M. Hoelzle. 2006. Coupling of a distributed glacier mass balance model to the regional climate model REMO: down-scaling strategy and first results. Geophys. Res. Abstr. 8, 09019. (1607-7962/gra/EGU06-A-09019.)

Paul, F., M. Maisch, C. Rothenbühler, M. Hoelzle and W. Haeberli. 2007a. Calculation and visualisation of future glacier extent in the Swiss Alps by means of hypsographic modelling. Global Planet. Change, 55(4), 343-357.
Paul, F., A. Kääb and W. Haeberli. 2007b. Recent glacier changes in the Alps observed from satellite: consequences for future monitoring strategies. Global Planet. Change, 56(1-2), 111-122.

Paul, F., H. Machguth, M. Hoelzle, N. Salzmann and W. Haeberli. In press. Alpine-wide distributed glacier mass balance modelling: a tool for assessing future glacier change? In Orlove, B., E. Wiegandt and B. Luckman, eds. The darkening peaks: glacial retreat in scientific and social context. Berkeley, CA, etc., University of California Press.

Rabatel, A., J.-P. Dedieu and C. Vincent. 2005. Using remotesensing data to determine equilibrium-line altitude and massbalance time series: validation on three French glaciers, 1994 2002. J. Glaciol., 51(175), 539-546.

Rabus, B., M. Eineder, A. Roth and R. Bamler. 2003. The shuttle radar topography mission: a new class of digital elevation models acquired by spaceborne radar. ISPRS J. Photogramm. Rem. Sens, 57(4), 241-262.

Raymond, C.F. and T.A. Neumann. 2005. Retreat of Glaciar Tyndall, Patagonia, over the last half-century. J. Glaciol., 51(173), 239-247.

Salzmann, N., C. Frei, P.L. Vidale and M. Hoelzle. 2007. The application of Regional Climate Model output for the simulation of high-mountain permafrost scenarios. Global Planet. Change, 56(1-2), 188-202.

Schöner, W. and R. Böhm. 2007. A statistical mass-balance model for reconstruction of LIA ice mass for glaciers in the European Alps. Ann. Glaciol., 46 (see paper in this volume).

Smiraglia, C., G. Diolaiuti, D. Casati and M.P. Kirkbride. 2000. Recent areal and altimetric variations of Miage Glacier (Monte Bianco massif, Italian Alps). IAHS Publ. 264 (Symposium at Seattle 2000 - Debris-Covered Glaciers), 227-233.

Steiner, D., A. Walter and H.J. Zumbühl. 2005. The application of a non-linear back-propagation neural network to study the mass balance of Grosse Aletschgletscher, Switzerland. J. Glaciol., $\mathbf{5 1}(173), 313-323$

Wild, M. and 9 others. 2005. From dimming to brightening: decadal changes in solar radiation at Earth's surface. Science, 308(5723), 847-850.

Zemp, M., W. Haeberli, M. Hoelzle and F. Paul. 2006. Alpine glaciers to disappear within decades? Geophys. Res. Lett., 33(L13), L13504. (10.1029/2006GL026319.)

Zemp, M., M. Hoelzle and W. Haeberli. 2007. Distributed modelling of the regional climatic equilibrium line altitude of glaciers in the European Alps. Global Planet. Change, 56(1-2) $83-100$.

\section{APPENDIX}

Table 3. Thickness changes from selected Alpine glaciers 1889-2000. Compilation and calculation from data of WGMS (http://www. wgms.ch) and Finsterwalder and Rentsch (1981)

\begin{tabular}{|c|c|c|c|c|c|c|}
\hline Political unit & Name & WGMS_ID & Survey year & Ref. year & $\begin{array}{l}\text { Thickness change } \\
\mathrm{mm}\end{array}$ & $\begin{array}{l}\text { Mean annual thickness change } \\
\qquad \mathrm{mm} \mathrm{a}^{-1}\end{array}$ \\
\hline AT & GEPATSCH F. & 522 & 1953 & 1922 & -15810 & -510 \\
\hline AT & GEPATSCH F. & 522 & 1958 & 1953 & 200 & 40 \\
\hline AT & GEPATSCH F. & 522 & 1971 & 1958 & 1040 & 80 \\
\hline AT & GEPATSCH F. & 522 & 1979 & 1971 & 1598 & 200 \\
\hline AT & GEPATSCH F. & 522 & 1990 & 1979 & -4357 & -396 \\
\hline AT & GEPATSCH F. & 522 & 1997 & 1990 & -3668 & -524 \\
\hline AT & GRUENAU F. & 599 & 1950 & 1932 & -10440 & -580 \\
\hline AT & GRUENAU F. & 599 & 1959 & 1950 & -2160 & -240 \\
\hline AT & GRUENAU F. & 599 & 1969 & 1959 & 3600 & 360 \\
\hline AT & GRUENAU F. & 599 & 1979 & 1969 & 1600 & 160 \\
\hline AT & GRUENAU F. & 599 & 1989 & 1979 & -1500 & -150 \\
\hline AT & GRUENAU F. & 599 & 1997 & 1989 & -3555 & -444 \\
\hline
\end{tabular}


Table 3. (continued)

Political unit Name WGMS_ID Survey year Ref. year Thickness change Mean annual thickness change
$\mathrm{mm} \quad \mathrm{mm} \mathrm{a}^{-1}$

\begin{tabular}{|c|c|c|c|c|c|c|}
\hline AT & GURGLER F. & 511 & 1981 & 1969 & -2581 & -215 \\
\hline AT & GUSLAR F. & 490 & 1912 & 1889 & -6440 & -280 \\
\hline AT & GUSLAR F. & 490 & 1938 & 1912 & -7020 & -270 \\
\hline AT & GUSLAR F. & 490 & 1969 & 1938 & -14260 & -460 \\
\hline AT & GUSLAR F. & 490 & 1979 & 1969 & 1474 & 147 \\
\hline AT & GUSLAR F. & 490 & 1990 & 1979 & -7802 & -709 \\
\hline AT & HINTEREIS F. & 491 & 1920 & 1894 & -9880 & -380 \\
\hline AT & HINTEREIS F. & 491 & 1940 & 1920 & -12600 & -630 \\
\hline AT & HINTEREIS F. & 491 & 1953 & 1940 & -11050 & -850 \\
\hline AT & HINTEREIS F. & 491 & 1959 & 1953 & -2880 & -480 \\
\hline AT & HINTEREIS F. & 491 & 1969 & 1959 & -1500 & -150 \\
\hline AT & HINTEREIS F. & 491 & 1979 & 1969 & -1363 & -136 \\
\hline AT & HINTEREIS F. & 491 & 1991 & 1979 & -9275 & -773 \\
\hline AT & HINTEREIS F. & 491 & 1997 & 1991 & -3509 & -585 \\
\hline AT & HORN K.(ZILLER) & 589 & 1950 & 1921 & -21460 & -740 \\
\hline AT & HORN K.(ZILLER) & 589 & 1960 & 1950 & 1400 & 140 \\
\hline AT & HORN K.(ZILLER) & 589 & 1969 & 1960 & 5220 & 580 \\
\hline AT & HORN K.(ZILLER) & 589 & 1979 & 1969 & 1748 & 175 \\
\hline AT & HORN K.(ZILLER) & 589 & 1989 & 1979 & -3508 & -351 \\
\hline AT & HORN K.(ZILLER) & 589 & 1996 & 1989 & -9459 & -1351 \\
\hline AT & SCHLEGEIS K. & 586 & 1950 & 1921 & -14210 & -490 \\
\hline AT & SCHLEGEIS K. & 586 & 1959 & 1950 & 2700 & 300 \\
\hline AT & SCHLEGEIS K. & 586 & 1969 & 1959 & 4100 & 410 \\
\hline AT & SCHLEGEIS K. & 586 & 1979 & 1969 & 2325 & 233 \\
\hline AT & SCHLEGEIS K. & 586 & 1989 & 1979 & -5888 & -589 \\
\hline AT & SCHLEGEIS K. & 586 & 1999 & 1989 & -9163 & -916 \\
\hline AT & SCHWARZENSTEIN & 588 & 1950 & 1921 & -24360 & -840 \\
\hline AT & SCHWARZENSTEIN & 588 & 1960 & 1950 & -700 & -70 \\
\hline AT & SCHWARZENSTEIN & 588 & 1969 & 1960 & 3150 & 350 \\
\hline AT & SCHWARZENSTEIN & 588 & 1979 & 1969 & 2869 & 287 \\
\hline AT & SCHWARZENSTEIN & 588 & 1989 & 1979 & -6361 & -636 \\
\hline AT & SCHWARZENSTEIN & 588 & 1999 & 1989 & -7489 & -749 \\
\hline AT & SULZENAU F. & 600 & 1950 & 1932 & -2700 & -150 \\
\hline AT & SULZENAU F. & 600 & 1959 & 1950 & -1800 & -200 \\
\hline AT & SULZENAU F. & 600 & 1969 & 1959 & 3300 & 330 \\
\hline AT & SULZENAU F. & 600 & 1979 & 1969 & 771 & 77 \\
\hline AT & SULZENAU F. & 600 & 1989 & 1979 & -4396 & -440 \\
\hline AT & SULZENAU F. & 600 & 1997 & 1989 & -4951 & -619 \\
\hline AT & SULZENAUF.STUBE & 1454 & 1989 & 1979 & -4810 & -481 \\
\hline AT & VERNAGT F. & 489 & 1912 & 1889 & -4830 & -210 \\
\hline AT & VERNAGT F. & 489 & 1938 & 1912 & -7540 & -290 \\
\hline AT & VERNAGT F. & 489 & 1969 & 1938 & -9300 & -300 \\
\hline AT & VERNAGT F. & 489 & 1979 & 1969 & 3043 & 304 \\
\hline AT & VERNAGT F. & 489 & 1982 & 1979 & -900 & -300 \\
\hline AT & VERNAGT F. & 489 & 1990 & 1982 & -4613 & -577 \\
\hline AT & VERNAGT F. & 489 & 1999 & 1990 & -7217 & -802 \\
\hline AT & WAXEGG $\mathrm{K}$. & 590 & 1950 & 1921 & -16530 & -570 \\
\hline AT & WAXEGG $\mathrm{K}$. & 590 & 1959 & 1950 & 2790 & 310 \\
\hline AT & WAXEGG $\mathrm{K}$. & 590 & 1969 & 1959 & 6700 & 670 \\
\hline AT & WAXEGG K. & 590 & 1979 & 1969 & 1547 & 155 \\
\hline AT & WAXEGG $\mathrm{K}$. & 590 & 1989 & 1979 & -2120 & -212 \\
\hline AT & WAXEGG K. & 590 & 2000 & 1989 & -9293 & -845 \\
\hline $\mathrm{CH}$ & GRIES & 359 & 1961 & 1923 & -31540 & -830 \\
\hline $\mathrm{CH}$ & GRIES & 359 & 1979 & 1961 & -1800 & -100 \\
\hline $\mathrm{CH}$ & GRIES & 359 & 1986 & 1979 & -2590 & -370 \\
\hline $\mathrm{CH}$ & GRIES & 359 & 1991 & 1986 & -6650 & -1330 \\
\hline $\mathrm{CH}$ & LIMMERN & 421 & 1977 & 1947 & -4347 & -145 \\
\hline $\mathrm{CH}$ & PLATTALVA & 420 & 1977 & 1947 & -5965 & -199 \\
\hline DE & BLAUEIS & 349 & 1980 & 1970 & 4196 & 420 \\
\hline DE & BLAUEIS & 349 & 1989 & 1980 & -6903 & -767 \\
\hline DE & HOELLENTAL & 348 & 1959 & 1950 & -1800 & -200 \\
\hline DE & HOELLENTAL & 348 & 1970 & 1959 & 3080 & 280 \\
\hline DE & HOELLENTAL & 348 & 1977 & 1970 & 772 & 110 \\
\hline DE & HOELLENTAL & 348 & 1981 & 1977 & 3373 & 843 \\
\hline DE & HOELLENTAL & 348 & 1989 & 1981 & -3612 & -452 \\
\hline $\mathrm{DE}$ & HOELLENTAL & 348 & 1997 & 1989 & -7579 & -947 \\
\hline
\end{tabular}


Table 3. (continued)

\begin{tabular}{|c|c|c|c|c|c|c|}
\hline Political unit & Name & WGMS_ID & Survey year & Ref. year & $\begin{array}{l}\text { Thickness change } \\
\mathrm{mm}\end{array}$ & $\begin{array}{l}\text { Mean annual thickness change } \\
\qquad \mathrm{mm} \mathrm{a}^{-1}\end{array}$ \\
\hline DE & SCHNEE F. North & 346 & 1949 & 1892 & -29070 & -510 \\
\hline DE & SCHNEE F. North & 346 & 1959 & 1949 & -6800 & -680 \\
\hline DE & SCHNEE F. North & 346 & 1971 & 1959 & -960 & -80 \\
\hline DE & SCHNEE F. North & 346 & 1979 & 1971 & 2567 & 321 \\
\hline DE & SCHNEE F. North & 346 & 1990 & 1979 & -4397 & -400 \\
\hline DE & SCHNEE F. North & 346 & 1997 & 1990 & -5705 & -815 \\
\hline DE & SCHNEE F. South & 347 & 1949 & 1892 & -50160 & -880 \\
\hline DE & SCHNEE F. South & 347 & 1959 & 1949 & -5700 & -570 \\
\hline DE & SCHNEE F. South & 347 & 1971 & 1959 & -1200 & -100 \\
\hline DE & SCHNEE F. South & 347 & 1979 & 1971 & 1923 & 240 \\
\hline DE & SCHNEE F. South & 347 & 1990 & 1979 & -4376 & -398 \\
\hline DE & SCHNEE F. South & 347 & 1997 & 1990 & -2864 & -409 \\
\hline DE & WATZMANNGL. & 350 & 1989 & 1980 & -3162 & -351 \\
\hline IT & CARESER & 635 & 1980 & 1967 & -3040 & -234 \\
\hline IT & CARESER & 635 & 1990 & 1980 & -11235 & -1124 \\
\hline IT & CARESER & 635 & 1997 & 1990 & -7750 & -1107 \\
\hline IT & CARESER & 635 & 2000 & 1997 & -7080 & -2360 \\
\hline IT & TYNDALL & 1202 & 1987 & 1947 & -3300 & -83 \\
\hline IT & TYNDALL & 1202 & 1993 & 1987 & -8200 & -1367 \\
\hline
\end{tabular}

Table 4. Decadal mean annual thickness change of selected Alpine glaciers (calculated from Table 3), 1890-1999. In addition, decadal standard deviations and number of included glaciers are given

\begin{tabular}{lccc}
\hline Decade & $\begin{array}{c}\text { Mean annual } \\
\text { thickness change }\end{array}$ & $\begin{array}{c}\text { Standard } \\
\text { deviation }\end{array}$ & $\begin{array}{c}\text { Number of } \\
\text { glaciers }\end{array}$ \\
& $\mathrm{mm}$ & 242 & \\
\hline $1890-99$ & -436 & 239 & $2-5$ \\
$1900-09$ & -452 & 230 & 5 \\
$1910-19$ & -462 & 205 & 5 \\
$1920-29$ & -586 & 216 & $5-11$ \\
$1930-39$ & -569 & 237 & $11-13$ \\
$1940-49$ & -562 & 324 & $13-16$ \\
$1950-59$ & -258 & 328 & 17 \\
$1960-69$ & +64 & 223 & $17-19$ \\
$1970-79$ & +110 & 318 & $19-21$ \\
$1980-89$ & -480 & 338 & $5-16$ \\
$1990-99$ & -828 & 264 & 12.5 \\
Mean & -405 & & \\
\hline
\end{tabular}

